Food Science and Applied Biotechnology, 2021, 4(2), 93-104
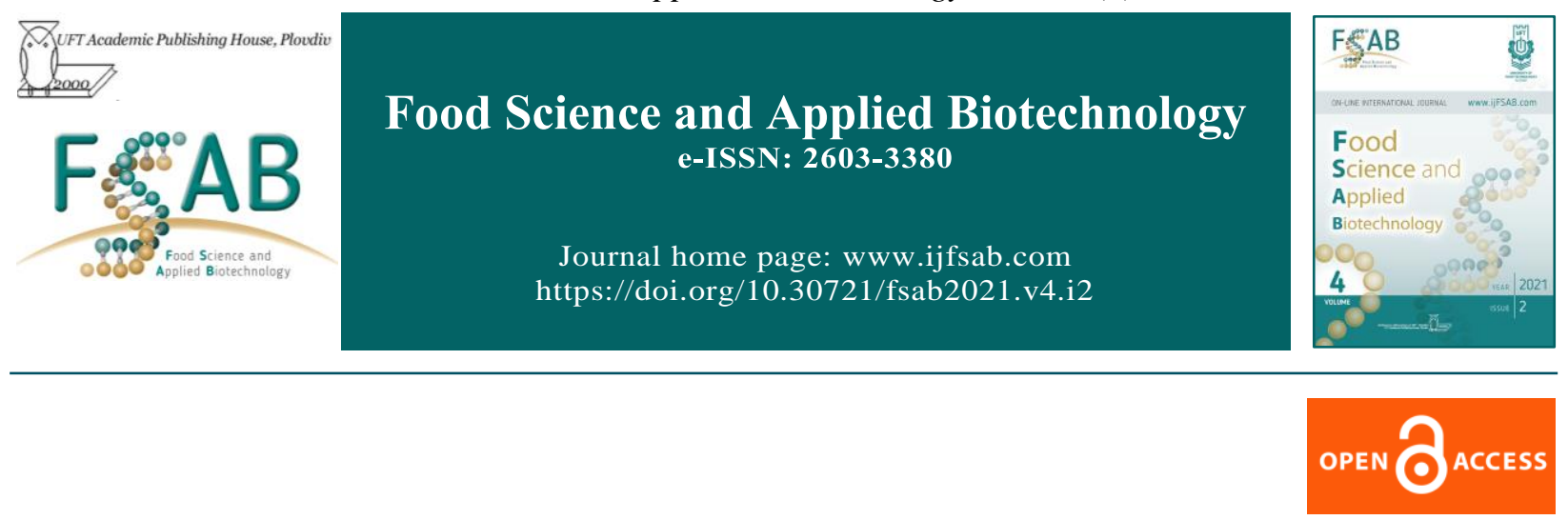

Research Article

\title{
Efficacy of flaxseed protein-based edible coatings on the quality of whole guava (Psidium guajava) during storage
}

\author{
Mohit Sharma ${ }^{\varpi 1}$, Charanjiv Singh Saini ${ }^{2}$ \\ ${ }^{1}$ Dr. S.S. Bhatnagar University Institute of Chemical Engineering \& Technology, Panjab University, Chandigarh- \\ 160014, India \\ ${ }^{2}$ Department of Food Engineering and Technology, Sant Longowal Institute of Food Engineering and Technology, \\ Longowal-148106, Sangrur, Punjab, India
}

\begin{abstract}
The objective of this study was to investigate the influence of flaxseed protein isolate coating solutions (FPC1 \& FPC2) comprising of flaxseed protein $\left(3 \% \mathrm{w} \mathrm{v}^{-1}\right.$ and $\left.5 \% \mathrm{w} \mathrm{v}^{-1}\right)$ enriched with $20 \%$ glycerol (on a protein isolate basis), tween-40 $\left(20 \% \mathrm{w} \mathrm{v}^{-1}\right)$ and $20 \%$ guar gum on the quality attributes of guava fruit stored under the controlled conditions of $65 \% \mathrm{RH}$ and $20^{\circ} \mathrm{C}$ temperature. The use of edible coatings notably delayed the spoilage of guava, which was examined by studying the quality parameters associated with the ripening of whole guavas. There was retardation of oxidative browning, polyphenol contents and reduction in ascorbic acid content as compared to control samples. Moreover, coating treatments predominately decrease the total plate counts, reflected in the Colony-forming unit (CFU g $\left.{ }^{-1}\right)$ and significantly $(\mathrm{p}<0.05)$ decrease the water loss. The non-coated samples of guavas showed a consistent reduction in lightness ( $\left.\mathrm{L}^{*}\right)$ values when confronted with coated fruits. Sensory scores for taste, colour, texture, flavour and overall acceptability were higher for all the coated samples than control (non-coated) samples of guavas. Thus, the flaxseed protein isolate-based coatings have shown the potential in protecting the quality attributes of guavas and enhance the shelf life up to 16 days.
\end{abstract}

Keywords: Flaxseed protein isolate, guar gum, total ascorbic content, total phenolic content, post-harvest storage

Abbreviations: CFU - Colony forming unit; FPC1 - Flaxseed protein isolate coating (3\%); FPC2 - Flaxseed protein isolate coating (5\%); TSS - Total soluble solids; TA - Titrable acidity

${ }^{\square}$ Corresponding author: Assistant Professor Mohit Sharma (Guest Faculty) Dr. S.S. Bhatnagar University Institute of Chemical Engineering \& Technology, Panjab University, Chandigarh -160014, India,Phone No.: +91-9872527559,E-mail : mohitlomash362@gmail.com

Article history:

Received 3 December 2020

Reviewed 19 May 2021

Accepted 21 June 2021

Available on-line 10 October 2021

https://doi.org/10.30721/fsab2021.v4.i2.132 (C) 2021 The Authors. UFT Academic publishing house, Plovdiv 


\section{Introduction}

Guava (Psidium guajava) is a climacteric fruit, which usually grows in tropical and subtropical countries of the world. It is a rich source of antioxidants, phenolic compounds, calcium and Vitamin C. It carries anti-inflammatory, antibacterial and free radical scavenging properties (McCook-Russell et al. 2012). In the case of climacteric fruits, respiration continues after the harvesting period. Ethylene production leads to the synthesis of volatile compounds, softening of tissue and chilling injury in fruits (Pech et al. 2008). Generally, low temperature and modified atmosphere techniques are used to control the ripening process.

Advanced technologies such as minimal processing technology aid in retaining the shelf life of food products. It can apply at multiple stages of food distribution channels such as storage, processing and packaging. Due to this, consumers can own food with a longer shelf life. Edible coating and edible films are thin layers, which can be applied to food products for the betterment and protection of food products. Films and coatings are usually composed of biodegradable sources such as proteins, carbohydrates, lipids and composite food materials. Anti-browning agents, plasticizers, herbal components, and essential oils can also be combined along with these biopolymers (Hassan et al. 2018). Edible coatings are effective in maintaining the sensory, microbiological and nutritional quality of food. Edible films and edible coatings act as transport substance in the delivery of bioactive materials (Falguera et al. 2011). Edible coatings act as a barrier to gases and moisture. They also reduce ethylene production and enzymatic browning in fruits (Baldwin et al. 1996).

Flaxseed (Linum usitatissimum) is a popular oilseed crop that belongs to Linaceae family chiefly famous for its fibres, proteins and polyunsaturated fatty acids. Moreover, flaxseed is well known for its antioxidant properties, antihypertensive activity and regulating the glycemic index response in humans. These effects last longer during the storage of products (Marpalle et al. 2014a; Marpalle et al. 2015b). Despite nutritional properties, Flaxseed has excellent physiochemical, functional and textural properties, which make flaxseed a valuable ingredient for the formation of edible films and coatings (Marpalle et al. 2014a; Kaushik et al. 2016). Very few studies have demonstrated the useful effect of flaxseed-based coatings on fruits such as pomegranate arils (Yousuf and Srivastava 2017), cantaloupe (Treviño-Garza et al. 2019) and pineapple (Treviño-Garza et al. 2017).

Flaxseed meal is a by-product recovered after oil extraction, which is mainly utilized as animal feed. Mueller et al. (2010) explained that defatted meal comprised of $1.67 \%$ fat, $43.3 \%$ protein, $6.40 \%$ ash,

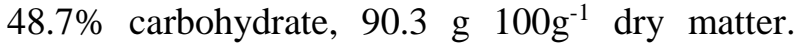
Flaxseed meal includes both $11 \mathrm{~S}$ (high molecular) and $2 \mathrm{~S}$ (low molecular weight) fractions of protein. It carries $22.8 \%$ glutamic acid, $10.4 \%$ arginine and $8.3 \%$ aspartic acid. Cysteine is a limiting amino acid among all varieties. $11 \mathrm{~S}$ proteins consist of five different polypeptide chains having a molecular weight of 11000, 18000, 29000, 42000 and 61000 daltons, respectively (Oomah and Mazza 1993). The edible coating formed from flaxseed protein isolate can offer a possibility to extend the shelf life of whole and cut fruit.

The present study was carried out to evaluate the effect of coatings based on flaxseed protein isolate on the shelf life and quality attributes of whole guava fruit.

\section{Materials and Methods}

\section{Raw material and treatments}

Flaxseeds (LC-2063) were purchased from Punjab Agricultural University, Ludhiana, Punjab, India and fresh guavas (Psidium guajava) were procured from the farm of Ghabdan, Sangrur, Punjab. Fresh guavas were selected with the same size, and colour for the experiment. Uniform sized guavas of diameter $30-40 \mathrm{~mm}$, average greenness ( $\mathrm{a}^{*}$ value of CIE scale) $-16.10 \pm 0.96$ and the average weight of 115-130 $\mathrm{g}$ were sorted and employed in the experiments. The initial weight of fresh guavas was measured using the electronic weighing balance (Afcoset, $\mathrm{GmbH}$ ) and diameter was observed with the help of a vernier calliper (Mitutoyo, Japan). The outer surface colour of guavas was measured by the Hunter Lab colour spectrometer (Gretag Macbeth, I-5, USA). Guavas were cleaned with $0.1 \%$ sodium hypochlorite solution for surface decontamination, washed with distilled water and dried at room temperature (Murmu and Mishra 2017). 


\section{Chemicals}

Food grade glycerol, Tween 40 and Guar gum was used for the preparation of coating solutions and were purchased from Sigma Aldrich (SigmaAldrich Chemicals Private Limited, Bangalore, India). All other chemicals used for analysis were of analytical grade and purchased from Mumbai, India.

\section{Preparation of coating solutions}

Flaxseed protein isolate having $94 \%$ purity was prepared by the alkali extraction technique as per the method by Kaushik et al. (2016) with slight modifications. Flaxseed protein isolate $(3 \%$ and $5 \%$ $\mathrm{W} \mathrm{V}^{-1}$ ) solutions were developed in distilled water by $\mathrm{pH}$ adjustment to 11 . The coating solution made by $3 \%$ concentration was regarded as FPC1 and the coating solution with $5 \%$ concentration was considered as FPC2. The denaturation was carried out at $90^{\circ} \mathrm{C}$ for $10 \mathrm{~min}$ on a hot water bath and then cooled at $25^{\circ} \mathrm{C} .20 \%$ glycerol (on a protein isolate basis) was added to the solution as a plasticizer agent. 20\% ( $\left.\mathrm{w} \mathrm{v}^{-1}\right)$ Tween-40 (on a total solution basis) was added as an emulsifier. 20\% Guar gum (on a protein isolate basis) was added to the coating solution to provide stability and consistency. The solution was stirred on a magnetic stirrer for $30 \mathrm{~min}$ for uniform mixing.

\section{Coating of fruits}

Fruit samples were coated with the help of the dipping method. Fruits were divided into three groups. Group A consisted of guavas in which no coating treatment was given and was considered as the control sample. Group B in which fruits were immersed in 3\% coating solution and Group C, in which fruits were immersed in 5\% coating solution. The coating given on the same day was considered as day 0 . Guavas were dipped in coating solution in a two-step process, each one of $2 \mathrm{~min}$. The guava samples were drained in a hot air oven at $25^{\circ} \mathrm{C}$ for 20 min following the primary step dipping, and 25 min for the secondary step dipping. After coating, fruits were stored in trays within an environmental chamber under controlled conditions of $65 \% \mathrm{RH}$ and $20^{\circ} \mathrm{C}$ temperature.

\section{Weight loss}

Weight loss was measured by determining the difference between the initial and final weight of each fruit and next dividing the difference by initial weight. Measurements were carried out subsequently on the $4^{\text {th }}, 8^{\text {th }}, 12^{\text {th }}$ and $16^{\text {th }}$ day of storage. The observed values were marked in the form of a percentage (\%).

\section{Firmness}

Firmness was determined by Texture Profile Analyzer (TA-XT2i, Stable Microsystem, Godalming, England) with a Probe (P/5). Pre-test speed set to $1 \mathrm{~mm} \mathrm{~s}^{-1}$ and post-test speed to $10 \mathrm{~mm}$ $\mathrm{s}^{-1}$. Three readings were evaluated at an equilateral diameter of guavas. Values of firmness were measured in Newton $(\mathrm{N})$.

\section{Colour values}

Colour values were observed in guavas with a Hunter Lab colour spectrometer (Gretag Macbeth, I-5, USA) at room temperature. Colour values were evaluated in the form of $\mathrm{L}^{*}, \mathrm{a}^{*}$ and $\mathrm{b}^{*}$.

\section{Total soluble solids (TSS) and Titrable acidity} (TA)

TSS content of the juice was determined as ${ }^{\circ}$ Brix with a digital refractometer calibrated with distilled water. $10 \mathrm{~g}$ sample of fruit pulp was diluted with 50 $\mathrm{ml}$ of distilled water and titrated with $0.1 \mathrm{~N} \mathrm{NaOH}$ until the endpoint was reached. Acidity was expressed in \% citric acid.

\section{Total sugars and reducing sugars}

Total sugar and reducing sugar content of guava pulp were measured according to the method of Lane and Eynon (Murmu and Mishra 2018). For the investigation of total and reducing sugars, mashed fruit pulp without peel employed and results were measured in percentage (\%).

\section{Ascorbic acid content}

Ascorbic acid content was measured according to 2, 6 dicholorophenolindophenol methods defined by Sharma and Saini (2021). The filtrate was titrated against 2, 6 dicholorophenolindophenol dye until a rose pink colour appeared. The amount of ascorbic acid content was represented as $\mathrm{mg} 100 \mathrm{~g}^{-1}$ fresh juice.

\section{Total phenolic content}

Total phenolic content was evaluated by exerting 10 $\mathrm{g}$ of guava pulp with the dilution of $30 \mathrm{ml}$ of water. $5 \mathrm{mg}$ of peel was diluted in $20 \mathrm{ml}$ of methanol and 
endured on the hot water bath for $24 \mathrm{~h} .1 \mathrm{ml}$ of extract carried out and firmly mixed with FolinCiocalteu reagent (thinned by ten folds) and $4 \mathrm{ml}$ of $\mathrm{Na}_{2} \mathrm{CO}_{3}$ solution $(7.5 \%)$. The mixture kept for 30 min in the dark, and spontaneously absorbance of the solution was observed at $765 \mathrm{~nm}$ with the help of a UV Spectrometer (UV-2100 UV/VIS Spectrophotometer, USA). The value of phenolic content stated in the form of mg GAE $100 \mathrm{~g}^{-1}$ (Kazemi et al. 2016).

\section{Total plate count}

Total plate count was determined by a method described by Marquez et al. (2017). $10 \mathrm{~g}$ of fruit pulp homogenized with $90 \mathrm{ml}$ of Ringer's solution. The dilutions were made from Ringer's solution and poured directly on agar and incubated at $37^{\circ} \mathrm{C}$ for $24 \mathrm{~h}$. Colonies were counted and measured as $\mathrm{CFU}$ $\mathrm{g}^{-1}$.

\section{Sensory analysis}

Sensory analysis of coated guavas was carried out on the first and last day of storage. Sixteen trained panellists between the ages of 30-50 years were chosen for sensory analysis from a group of Department of Food Engineering and Technology, SLIET, Longowal. The selected assessors had a decent knowledge about sensory evaluation and fruit acceptability trend. The sensory analysis was carried out by using a nine-point Hedonic scale (1= most disliked attribute, $9=$ most liked attribute). Scores $\geq 5$ were "satisfactory". Samples were coded with three different codes and trained panellists were asked to rank scores for colour, texture, taste, flavour and overall acceptability. The overall acceptability was judged based on skin damage, shrinkage, off flavour, inappropriate ripening and over-ripening (Murmu and Mishra 2017; Brasil et al. 2012). The assessors used water to rinse in between sampling and recorded their responses on paper scorecards.

\section{Decay percentage}

Decay percentage of coated and non-coated whole fruit guava was determined by dividing the decayed samples with primary day samples from every group (Nawab et al. 2017).

\section{Statistical Analysis}

The impact of different concentrations on the whole fruit guavas was analysed by evaluating data with one way ANOVA process. The entire tests were performed in triplicates and their mean values were evaluated by using Statistical software (SPSS Statistics 23, IBM, New York, USA). Tukey's test was employed to investigate the significant differences $(p \leq 0.05)$ in different quality attributes of fruit.

\section{Results and Discussion}

\section{Weight loss and firmness (\%)}

During ripening and storage, some fruits undergo a reduction in weight loss (Fig. 1) and firmness (Fig. 2 ), which ultimately decreased the shelf life of fruits.

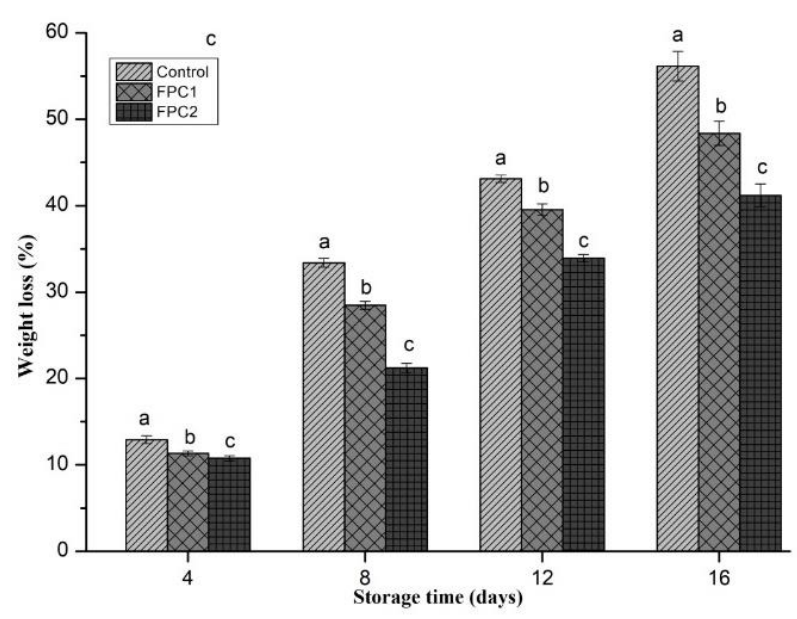

Figure 1. Weight loss (\%) of guavas stored at $20^{\circ} \mathrm{C}$ for 16 days; Control - Non-coated sample; FPC1Flaxseed protein isolate coating (3\%); FPC2Flaxseed protein isolate coating (5\%); Error bars designate the standard deviation for triplicate analyses; Bars followed by different letters, on the same day of storage, designate statistical difference in treatment $(\mathrm{p}<0.05)$ 


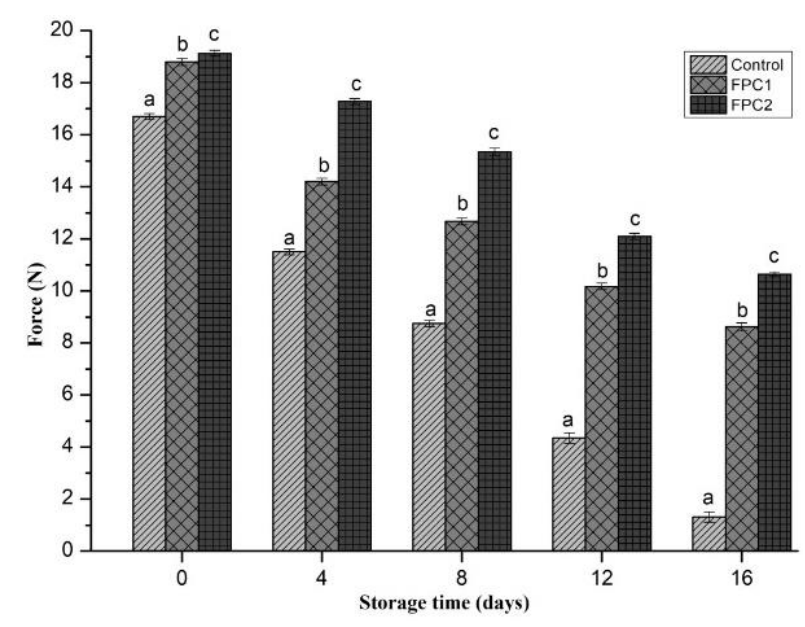

Figure 2. Firmness (Force in $\mathrm{N}$ ) of guavas stored at $20^{\circ} \mathrm{C}$ for 16 days; Control - Non-coated sample; $\mathrm{FPC} 1=$ Flaxseed protein isolate coating $(3 \%)$; FPC2 $=$ Flaxseed protein isolate coating (5\%); Error bars designate the standard deviation for triplicate analyses; Bars followed by different letters, on the same day of storage, designate statistical difference in treatment $(\mathrm{p}<0.05)$

The result showed that the highest percentage of weight loss was observed in the controlled sample on the $16^{\text {th }}$ day of storage, which was found to be $56.14 \%$. Among the coated samples, the lowest per cent weight loss was observed for the FPC2 sample $(10.76 \%) 4^{\text {th }}$ day of storage. This may be because of the good water barrier property of coating prepared from flaxseed proteins. Transpiration is the process occurring in plants, which is responsible for the weight loss in fruits. Layers like the epidermal cell layer and cuticle reduce the rate of transpiration. The edible coating coats the surface and acts as a barrier layer, which reduces the transpiration rate (Mannozzi et al. 2017). At the end day of storage, a maximum and minimum amount of weight loss was observed in control and FPC2 (14.94\% lower than control) treated fruits, respectively. Similar results were observed in other fruits also like strawberries (Ventura-Aguilar et al. 2018) and apricot (Zhang et al. 2018).

Firmness is an important factor that determines a consumer's acceptability. The reduction in firmness is mainly because of weight loss and moisture loss. During the ripening process, the pectin and hemicelluloses solubilize and de-polymerize, which results in loosening and disintegration of the cell wall. The edible coating helps in maintaining the firmness by reducing the rate of transpiration and respiration, slows down the ripening, delay senescence and retard cell wall degradation (Paniagua et al. 2013). As shown in Figure 2 reduction in firmness was observed for non-coated samples, which might be because of degradation of the cell wall and loss of extracellular and vascular air, whereas the coated samples retained the firmness better as compared to the non-coated samples. On the end of storage, the highest firmness was observed in FPC2 treated fruits $(10.64 \mathrm{~N})$, which was $9.33 \%$ firmer than control samples (1.31 $\mathrm{N})$. FPC1 retained $2.02 \%$ lesser firmness as compared to FPC2 treated samples (Fig. 2). A similar trend was found in guavas coated with chitosan, which retained better firmness as compared to uncoated samples (Hong et al. 2012).

\section{Colour}

The quality of fruit is mainly affected by enzymatic browning, which occurs due to peroxidase and polyphenol oxidase (Fratianni et al. 2013). Colour Spectrophotometer determined the colour of the samples and the results are depicted in Table 1 in the form of $L^{*}, a^{*}, b^{*}$, where $L^{*}$ represents the level of intensity of lightness/darkness, a* represents the difference between red/green colour and $b^{*}$ tells about yellow/blue colour. Peel colour is a vital aspect that evaluates the quality of fruit in the form of ripening and maturity (Nair et al. 2018). The L* values were decreased for all the samples during the storage period. The difference in lightness values obtained in the fruits treated with FPC1 and FPC2 was $14.76 \%$ and $18.74 \%$ compared to the control samples of guavas. The decreases in $\mathrm{L}^{*}$ indicates the browning of skin tissue. $a^{*}$ values increased during storage study which represents the reduction in greenness. On the $16^{\text {th }}$ day, the lowest $a^{*}$ index value was found in fruit treated with FPC2 (-11.05) and FPC2 (-9.32), respectively (Table 1). The reduction of $b^{*}$ index values was observed during the storage study of guavas. The highest value was found in the case of samples treated with FPC2 (37.33) accompanied by FPC1 (36.66) treatment, respectively. The reason for the reduction in $b^{*}$ index values is due to the reduction of chlorophyll and the formation of carotenoid 
Food Science and Applied Biotechnology, 2021, 4(2), 93-104

Table 1 Colour values of guavas stored at $20^{\circ} \mathrm{C}$ for 16 days

\begin{tabular}{llccccc}
\hline Colour Values & Coating & \multicolumn{1}{c}{0 day } & $4^{\text {th }}$ day & $8^{\text {th }}$ day & $12^{\text {th }}$ day & $16^{\text {th }}$ day \\
\hline$L^{*}$ & Control & $59.68^{\mathrm{a}} \pm 1.01$ & $56.92^{\mathrm{c}} \pm 0.56$ & $49.12^{\mathrm{c}} \pm 2.61$ & $48.36^{\mathrm{c}} \pm 1.55$ & $47.15^{\mathrm{c}} \pm 2.99$ \\
& FPC1 & $59.68^{\mathrm{a}} \pm 1.01$ & $58.21^{\mathrm{b}} \pm 0.98$ & $57.33^{\mathrm{a}} \pm 3.11$ & $56.36^{\mathrm{b}} \pm 0.25$ & $54.11^{\mathrm{b}} \pm 2.11$ \\
$a^{*}$ & FPC2 & $59.68^{\mathrm{a}} \pm 1.01$ & $59.42^{\mathrm{a}} \pm 0.05$ & $57.21^{\mathrm{b}} \pm 2.88$ & $56.77^{\mathrm{a}} \pm 0.66$ & $55.99^{\mathrm{a}} \pm 1.66$ \\
& Control & $-16.10^{\mathrm{a}} \pm 0.96$ & $-14.68^{\mathrm{a}} \pm 2.35$ & $-13.36^{\mathrm{a}} \pm 2.15$ & $-11.21^{\mathrm{a}} \pm 0.99$ & $-6.22^{\mathrm{a}} \pm 3.09$ \\
& FPC1 & $-16.10^{\mathrm{a}} \pm 0.96$ & $-15.25^{\mathrm{b}} \pm 1.25$ & $-14.89^{\mathrm{b}} \pm 0.22$ & $-13.55^{\mathrm{b}} \pm 1.55$ & $-9.32^{\mathrm{b}} \pm 2.88$ \\
$b^{*}$ & FPC2 & $-16.10^{\mathrm{a}} \pm 0.96$ & $-15.55^{\mathrm{c}} \pm 1.07$ & $-15.11^{\mathrm{c}} \pm 0.56$ & $-14.11^{\mathrm{c}} \pm 0.66$ & $-11.05^{\mathrm{c}} \pm 2.78$ \\
& Control & $42.82^{\mathrm{a}} \pm 1.24$ & $38.41^{\mathrm{c}} \pm 1.57$ & $30.22^{\mathrm{c}} \pm 2.19$ & $32.22^{\mathrm{c}} \pm 1.11$ & $30.76^{\mathrm{c}} \pm 1.56$ \\
& FPC1 & $42.82^{\mathrm{a}} \pm 1.24$ & $40.44^{\mathrm{b}} \pm 0.88$ & $39.44^{\mathrm{b}} \pm 1.05$ & $37.26^{\mathrm{b}} \pm 2.73$ & $36.66^{\mathrm{b}} \pm 1.22$ \\
& FPC2 & $42.82^{\mathrm{a}} \pm 1.24$ & $41.39^{\mathrm{a}} \pm 1.36$ & $41.33^{\mathrm{a}} \pm 0.88$ & $38.55^{\mathrm{a}} \pm 0.97$ & $37.33^{\mathrm{a}} \pm 0.99$
\end{tabular}

Control = Non-coated sample; FPC1= Flaxseed protein isolate coating (3\%); FPC2= Flaxseed protein isolate coating (5\%); the data described as Mean values \pm Standard deviations accompanied by various superscript letters; For individual treatment, different letters in the same column designate significant differences $(\mathrm{p}<0.05)$ between the mean values as per the Tukey's test

pigments (Murmu and Mishra 2018; Nair et al. 2018). Therefore, due to a decline in chlorophyll pigment colour during the storage period, guavas becomes less green and more darker. This indicates that the use of FPC1 and FPC2 coatings exhibited a positive effect on the colour and reduction in the ripening of guavas. Similar results were reported by Etemadipoor et al. (2019) for guava fruits coated with gum Arabic.

\section{Total soluble solids (TSS)}

TSS of both the coated and uncoated samples increased with an increase in storage life. The results of TSS are presented in Figure 3.

However, the coated samples showed a lesser increase in TSS than the uncoated samples. All the three samples i.e. control sample, FPC1, and FPC2 sample had $8.90^{\circ}$ Brix TSS at 0 day i.e. on the day of coating, which increased to $12.3,11.9,11.5$ respectively, on the end day. This could be due to the reason that coating reduces the production of ethylene and the rate of respiration (Etemadipoor et al. 2019) and reduces the rate of synthesis and utilization of metabolites, delaying nutrient decomposition and as a result, a lower TSS values in coated samples were there as compared to noncoated samples (Dong and Wang 2018; Naeem et al. 2018). Therefore, FPC1 and FPC2 treated samples retained the TSS values more as compared to the control sample at the end of storage study. Similar results were reported by Yan et al. (2019) for strawberries coated with chitosan.

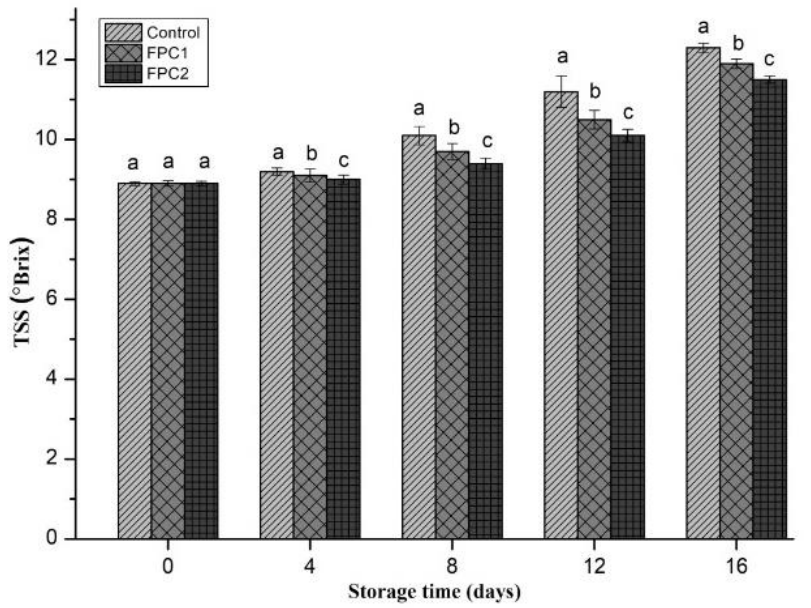

Figure 3. Total soluble solids ( ${ }^{\circ}$ Brix) of guavas stored at $20^{\circ} \mathrm{C}$ for 16 days; Control - Non-coated sample; FPC1 - Flaxseed protein isolate coating (3\%); FPC2 - Flaxseed protein isolate coating (5\%); Error bars designate the standard deviation for triplicate analyses; Bars followed by different letters, on the same day of storage, designate statistical difference in treatment $(p<0.05)$

\section{Titrable acidity (TA)}

The results of TA are presented in Figure 4. It showed that TA of all the samples decreased with an increase in storage life. The percentage decreased in TA was found to be highest in a non-coated sample. 


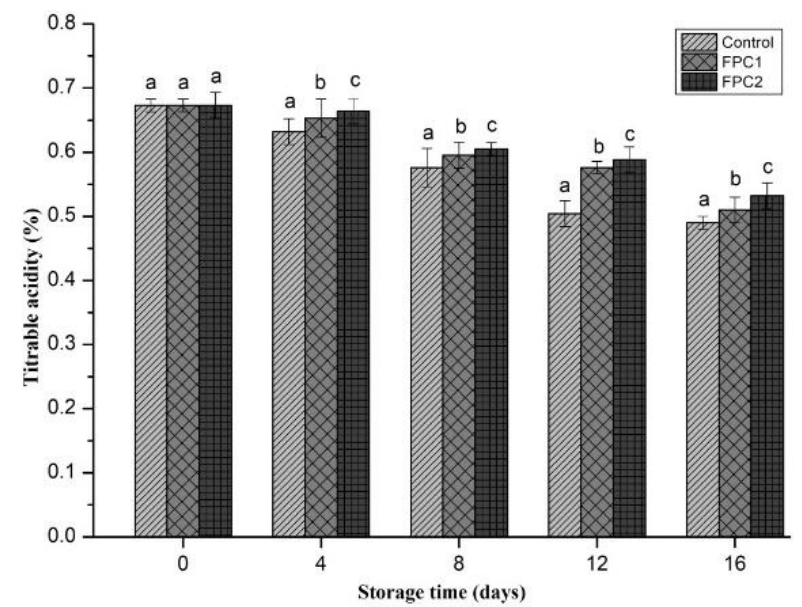

Figure 4. Titrable acidity (\%) of guavas stored at $20^{\circ} \mathrm{C}$ for 16 days; Control - Non-coated sample; FPC1 - Flaxseed protein isolate coating (3\%); FPC2 - Flaxseed protein isolate coating (5\%); Error bars designate the standard deviation for triplicate analyses; Bars followed by different letters, on the same day of storage, designate statistical difference in treatment $(\mathrm{p}<0.05)$

The initial TA of all the samples i.e. control, FPC1 and FPC2 found to be $0.673 \%$, which significantly ( $p<0.05$ ) reduced to $0.490 \%, 0.510 \%, 0.532 \%$ on the $16^{\text {th }}$ day of storage, respectively. Titrable acidity is a vital factor that signifies the eating quality of fruit. Usually, organic acids act as primary substrates involved in the respiration process and other metabolic processes. In guavas, citric acid is a chief organic acid employed in these processes (DeAquino et al. 2015). The coating act as a semipermeable membrane against respiration, which reduces the rate of respiration and further reduces the consumption of organic acids; therefore, the TA decreased (Riva et al. 2020; Mahfoudhi and Hamid 2014). Accordingly coated samples manifested a positive effect on controlling the respiration and maintaining the quality of guavas during the storage period. A similar trend was reported by Valero et al. (2013) in alginate coated plums.

\section{Total sugars and reducing sugars (\%)}

Various polysaccharides present in fruits get hydrolysed and increase total sugar and reducing sugar content. The result of total sugar and reducing sugar are presented in Figure 5 and Figure 6.

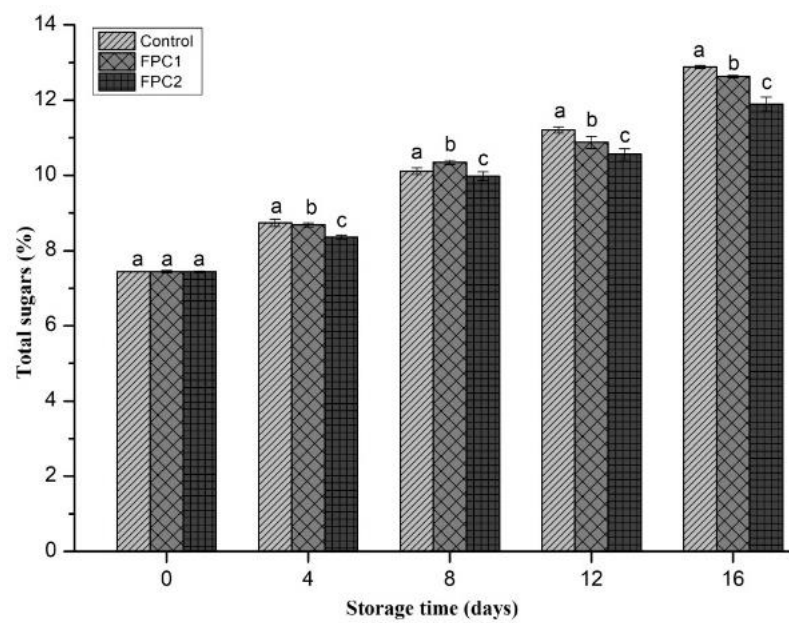

Figure 5. Total sugars $(\%)$ of guavas stored at $20^{\circ} \mathrm{C}$ for 16 days; Control - Non-coated sample; FPC1Flaxseed protein isolate coating (3\%); FPC2Flaxseed protein isolate coating (5\%); Error bars designate the standard deviation for triplicate analyses; Bars followed by different letters, on the same day of storage, designate statistical difference in treatment $(\mathrm{p}<0.05)$

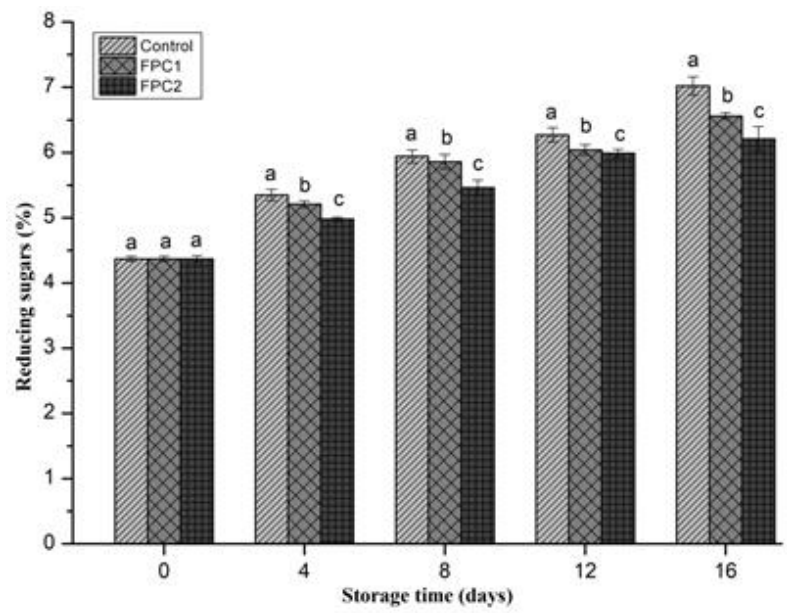

Figure 6. Reducing sugars (\%) of guavas stored at $20^{\circ} \mathrm{C}$ for 16 days; Control - Non-coated sample; FPC1 - Flaxseed protein isolate coating (3\%); FPC2 - Flaxseed protein isolate coating (5\%); Error bars designate the standard deviation for triplicate analyses; Bars followed by different letters, on the same day of storage, designate statistical difference in treatment $(\mathrm{p}<0.05)$

All the control and coated samples showed an increase in sugar and reducing sugar content with an increase in storage time. On the $16^{\text {th }}$ day, the 
increase in total sugar content in control, FPC1 and FPC2 samples was found to be $73.11 \%, 69.75 \%$ and $59.81 \%$, respectively. The highest percentage increase was found in the control samples followed by FPC1 treated fruits. The per cent increase in reducing sugar for control, FPC1, FPC2 sample was found to be $60.64 \%, 50.11 \%$ and $42.10 \%$ on the last day of storage, respectively. The coating acts as a barrier to the biosynthesis of guava, which results in the slow conversion of polysaccharides into sugars. Murmu and Mishra (2017) observed the same trend in guavas coated by Arabic gum, sodium caseinate and essential oils of cinnamon and lemongrass.

\section{Ascorbic acid}

Ascorbic acid present in fruits gets oxidized by the enzyme ascorbic acid oxidase, which results in the reduction of ascorbic acid content (Sarpong et al. 2018). The result of the change in ascorbic acid content with storage are presented in Figure 7 which showed that the ascorbic acid content of all samples significantly decreased $(p<0.05)$ with an increased in storage life.

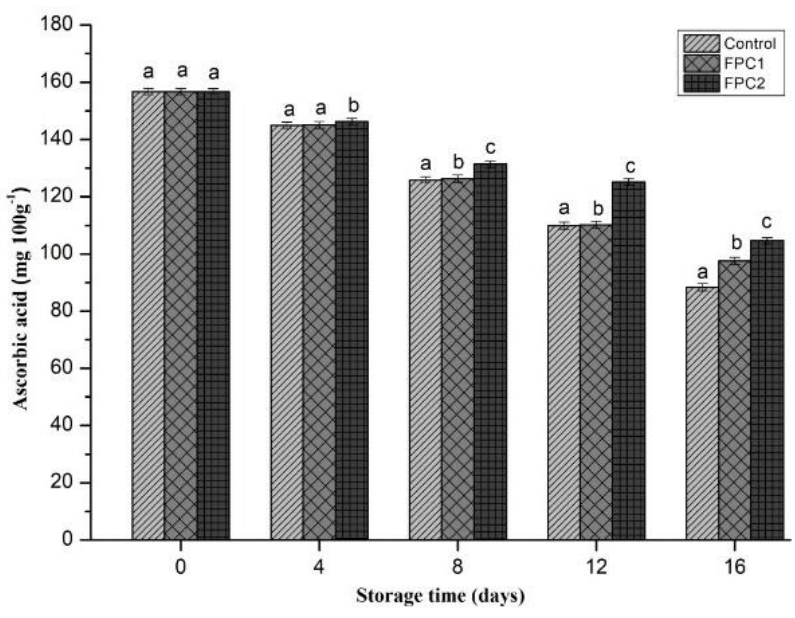

Figure 7. Ascorbic acid $\left(\mathrm{mg} 100 \mathrm{~g}^{-1}\right)$ of guavas stored at $20^{\circ} \mathrm{C}$ for 16 days; Control - Non-coated sample; FPC1 - Flaxseed protein isolate coating (3\%); FPC2 - Flaxseed protein isolate coating (5\%); Error bars designate the standard deviation for triplicate analyses; Bars followed by different letters, on the same day of storage, designate statistical difference in treatment $(p<0.05)$
On the last day of storage, the percentage decrease in ascorbic acid content in control, FPC1, FPC2 samples were found to be $44 \%, 38 \%$, and $33 \%$ respectively. The coated samples showed a significantly $(p<0.05)$ less reduction in ascorbic acid content as compared to the control sample. FPC2 sample showed the lowest percentage decrease. Autoxidation is a process occurring in fruits in which ascorbic acid combine with oxygen during respiration, which might be responsible for the decrease in ascorbic acid content. The edible coating acts as a covering layer and prevents the autoxidation process and because of this a less decrease in percentage ascorbic acid content was observed (Sharma and Rao 2015). Similar results were obtained by Loay and Taher (2018) in guavas coated by chitosan, polyvinyl pyrrolidine and salicylic acid.

\section{Total phenolic content}

Phenolic compounds are the secondary metabolites produced by plants to protect against oxidative attacks. Total phenolic content (TPC) depend on the species, cultivar, temperature and various environmental conditions. As shown in Figure 8, TPC in all the samples decreased with an increase in storage life.

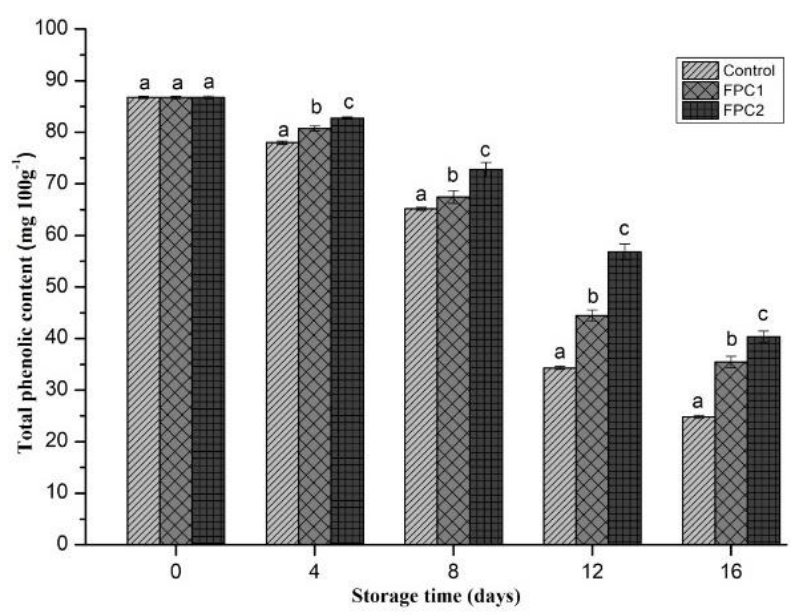

Figure 8. Total phenolic content (mg $100 \mathrm{~g}^{-1}$ ) of guavas stored at $20^{\circ} \mathrm{C}$ for 16 days; Control - Noncoated sample; FPC1 - Flaxseed protein isolate coating (3\%); FPC2 - Flaxseed protein isolate coating (5\%); Error bars designate the standard deviation for triplicate analyses; Bars followed by different letters, on the same day of storage, designate statistical difference in treatment $(\mathrm{p}<$ 0.05 ) 
On the last day of storage, the per cent decrease in control, FPC1 and FPC2 samples were found to be $71.42 \%, 59.15 \%$ and $53.46 \%$ compared to the initial day of storage, respectively. The highest TPC values were observed in fruit treated with FPC2 and FPC1 with $38.59 \%$ and $30.03 \%$ difference compared to control samples, respectively. The edible coating produces some stress on fruits, which affect the metabolism and production of total phenolic compounds (Tahir et al. 2019). This might be the reason for less decrease of TPC in coated samples. Feng et al. (2018) observed a similar trend in apples coated by whey protein isolate nanofibrils.

\section{Total plate count}

All the coated samples exhibited less total plate count as compared to non-coated samples (Table 2). On the $8^{\text {th }}$ day of storage, non-coated fruit samples showed a significantly higher $(p<0.05)$ microbial growth of $7.7 \times 10^{3} \mathrm{CFU} \mathrm{g}^{-1}$.
On the $16^{\text {th }}$ day, the total plate count was found to be $1.8 \times 10^{6} \mathrm{CFU} \mathrm{g}^{-1}$ in control samples accompanied by FPC1 and FPC2 treated samples respectively, which denotes the higher ripening rate in the noncoated sample. Fruits treated with FPC2 coating were considered more influential as compared to FPC1 treated samples. Over ripening leads to the spoilage of fruit samples. Bierhals et al. (2011) reported that microbial count below $1 \times 10^{6} \mathrm{CFU} \mathrm{g}^{-1}$ is considered to be acceptable for all fruit-based products. De-Aquino et al. (2015) reported a positive effect of chitosan-cassava starch-based coating in maintaining the quality of guavas.

\section{Sensory analysis}

The sensory scoring of whole guava fruit was determined on the 0 and $16^{\text {th }}$ day of storage (Table 3).

Table 2. Total plate count (CFU/g) of guavas stored at $20^{\circ} \mathrm{C}$ for 16 days

\begin{tabular}{cccc}
\hline Treatment & 0 day & $8^{\text {th }}$ day & $16^{\text {th }}$ day \\
\hline Control & $<10^{\mathrm{a}}$ & $7.7 \times 10^{3 \mathrm{a}}$ & $1.8 \times 10^{6 \mathrm{c}}$ \\
FPC1 & $<10^{\mathrm{a}}$ & $2.27 \times 10^{3 \mathrm{~b}}$ & $8.1 \times 10^{3 \mathrm{a}}$ \\
FPC2 & $<10^{\mathrm{a}}$ & $<10^{\mathrm{c}}$ & $3.1 \times 10^{2 \mathrm{~b}}$ \\
\hline
\end{tabular}

Control = Non-coated sample; FPC1 - Flaxseed protein isolate coating (3\%); FPC2 - Flaxseed protein isolate coating (5\%); For individual treatment, different letters in the same column designate significant differences $(\mathrm{p}<0.05)$ between the mean values as per the Tukey's test

Table 3. Sensory evaluation scores of coated and non-coated guavas stored at $20^{\circ} \mathrm{C}$ for 16 days

\begin{tabular}{llllllc}
\hline \multirow{2}{*}{ Sensory attributes } & \multicolumn{2}{c}{ Control } & \multicolumn{2}{c}{ FPC1 } & \multicolumn{2}{c}{ FPC2 } \\
& 0 day & $16^{\text {th }}$ day & 0 day & $16^{\text {th }}$ day & 0 day & $16^{\text {th }}$ day \\
\hline Colour & $9.0^{\mathrm{a}} \pm 0.05$ & $4.6^{\mathrm{c}} \pm 1.14$ & $8.9^{\mathrm{b}} \pm 0.11$ & $7.2^{\mathrm{b}} \pm 0.43$ & $8.9^{\mathrm{b}} \pm 0.22$ & $8.4^{\mathrm{a}} \pm 0.51$ \\
Texture & $8.5^{\mathrm{a}} \pm 0.11$ & $4.6^{\mathrm{c}} \pm 0.54$ & $8.5^{\mathrm{a}} \pm 0.24$ & $7.0^{\mathrm{b}} \pm 0.58$ & $8.4^{\mathrm{b}} \pm 0.15$ & $7.6^{\mathrm{a}} \pm 0.54$ \\
Taste & $8.7^{\mathrm{b}} \pm 0.15$ & $3.6^{\mathrm{c}} \pm 0.84$ & $8.7^{\mathrm{b}} \pm 0.21$ & $7.8^{\mathrm{b}} \pm 0.51$ & $8.8^{\mathrm{a}} \pm 0.12$ & $8.6^{\mathrm{a}} \pm 0.42$ \\
Flavour & $8.8^{\mathrm{a}} \pm 0.21$ & $6.6^{\mathrm{c}} \pm 0.89$ & $8.8^{\mathrm{a}} \pm 0.20$ & $8.0^{\mathrm{a}} \pm 0.62$ & $8.6^{\mathrm{b}} \pm 0.24$ & $7.0^{\mathrm{b}} \pm 0.44$ \\
OA & $8.5^{\mathrm{b}} \pm 0.31$ & $5.0^{\mathrm{c}} \pm 0.70$ & $8.6^{\mathrm{a}} \pm 0.30$ & $7.2^{\mathrm{b}} \pm 0.51$ & $8.6^{\mathrm{a}} \pm 0.12$ & $8.2^{\mathrm{a}} \pm 0.56$ \\
\hline
\end{tabular}

Control = Non-coated sample; FPC1 - Flaxseed protein isolate coating (3\%); FPC2 - Flaxseed protein isolate coating (5\%); OA - Overall acceptability; the data described as Mean values \pm Standard deviation accompanied by various letters for individual treatment, Different letters in the same column and on alternate days designate significant differences $(\mathrm{p}<0.05)$ between the mean values as per the Tukey's test 
All the coated samples were acceptable at the end of the storage period. All the coated samples exhibited a higher score of colour, texture, taste, flavour and overall acceptability scores than non-coated samples. On the last day of storage, the lower sensory scores were observed in control samples due to consequent changes in colour, taste and flavour. Also, the coating solutions comprising of protein isolate showed no adverse effect on colour, texture, taste, and flavour scores. The results are in agreement with Saberi et al. (2018) for Valencia oranges coated with pea starch and guar gum.

\section{Decay percentage}

Protein coatings successfully delayed the senescence and ripening of whole guava fruits till the $16^{\text {th }}$ day of storage. Non coated guavas were completely decayed on the $10^{\text {th }}$ day of storage. Early ripening in non-coated samples leads to cell tissue rupture, which makes fruits more prone to fungal growth (Moreira et al. 2020; Nawab et al. 2017) reported a similar trend for starch coated tomato fruit.

\section{Conclusions}

Coatings made from flaxseed protein isolate could be used to prevent the post-harvest losses and climacteric ripening of guava fruits. All coated samples exhibited a lesser increase in total sugars and reducing sugars than non-coated samples. All coated samples recorded lesser weight loss, lower increase in TSS and a more moderate decrease in acidity after 16 days of storage. Sensory scores for odour, colour and texture were leading for all coated samples than non-coated samples. The browning in guava fruit is associated with enzymatic activities. Coatings obtained from flaxseed were beneficial in controlling the browning activities during the storage study. Edible coatings limit the cell wall degradation enzymatic activities and protect ascorbic acid contents from oxidation. All coated samples recorded effective retention in firmness than non-coated samples as well as coated samples exhibit antimicrobial properties. Coated samples manifested less plate count as compared to noncoated samples. It is concluded that edible coatings obtained from flaxseed can be considered as a powerful tool in maintaining the quality attributes of guavas after the harvesting. However, more studies need to be conducted to explore the potential of edible coatings obtained from flaxseed protein isolate.

\section{Acknowledgements}

The authors are grateful to Sant Longowal Institute of Engineering and Technology, Longowal, Sangrur, India for providing necessary infrastructural facilities for completing this research work.

\section{References}

Baldwin, E.A., Nisperos, M.O., Chen, X., Hagenmaier, R.D. Improving storage life of cut apple and potato with edible coating. Postharvest Biology and Technology, 1996, 9, 151-163. http://dx.doi.org/10.1016/s0925-5214(96)00044-0

Bierhals, V.S., Chiumarelli, M., Hubinger, M.D. Effect of cassava starch coating on quality and shelf life of fresh-cut pineapple (Ananas comosus L. Merril cv "Perola"). Journal of Food Science, 2011, 76, E62E72. http://dx.doi.org/10.1111/j.17503841.2010.01951.X

Brasil, I.M., Gomes, C., Puerta-Gomez, A., CastellPerez, M.E., Moreira, R.G. Polysaccharide-based multilayered antimicrobial edible coating enhances quality of fresh-cut papaya. LWT - Food Science and Technology, 2012, 47, 39-45. http://dx.doi.org/10.1016/j.lwt.2012.01.005

De-Aquino, A.B., Blank, A.F., De-Aquino Santana, L.C.L. Impact of edible chitosan-cassava starch coatings enriched with Lippia gracilis Schauer genotype mixtures on the shelf life of guavas (Psidium guajava L.) during storage at room temperature. Food Chemistry, 2015, 171, 108-116. http://dx.doi.org/10.1016/j.foodchem.2014.08.077

Dong, F., Wang, X. Guar gum and ginseng extract coatings maintain the quality of sweet cherry. LWT Food Science and Technology, 2018, 89, 117-122. http://dx.doi.org/10.1016/j.lwt.2017.10.035

Etemadipoor, R., Ramezanian, A., Dastjerdi, A.M., Shamili, M. The potential of gum arabic enriched with cinnamon essential oil for improving the qualitative characteristics and storability of guava (Psidium guajava L.) fruit. Scientia Horticulturae, 2019, 251, 101-107. http://dx.doi.org/10.1016/j.scienta.2019.03.021 Falguera, V., Quintero, J.P., Jimenez, A., Munoz, J.A., Ibarz, A. Edible films and coatings: Structures, active functions and trends in their use. Trends in 
Food Science and Technology, 2011, 22, 292-303. http://dx.doi.org/10.1016/j.tifs.2011.02.004

Feng, Z., Wu, G., Liu, C., Li, D., Jiang, B., Zhang, X. Edible coating based on whey protein isolate nanofibrils for antioxidation and inhibition of product browning. Food Hydrocolloids, 2018, 79, 179-188. http://dx.doi.org/10.1016/j.foodhyd.2017.12.028

Fratianni, A., Albanese, D., Mignogna, R., Cinquanta, L., Panfili, G., Di Matteo, M. Degradation of carotenoids in apricot (Prunus armeniaca L.) during drying process. Plant Foods for Human Nutrition, 2013, 68, 241-246. http://dx.doi.org/10.1007/s11130-013-0369-6

Hassan, B., Chatha, S.A.S., Hussain, A.I., Zia, K.M., Akhtar, N. Recent advances on polysaccharides, lipids and protein based edible films and coatings: A review. International Journal of Biological Macromolecules, 2018, 109, 1095-1107. http://dx.doi.org/10.1016/j.ijbiomac.2017.11.097

Hong, K., Xie, J., Zhang, L., Sun, D., Gong, D. Effects of chitosan coating on postharvest life and quality of guava (Psidium guajava L.) fruit during cold storage. Scientia Horticulturae, 2012, 144, 172-178. http://dx.doi.org/10.1016/j.scienta.2012.07.002

Kaushik, P., Dowling, K., Mcknight, S., Barrow, C.J., Wang, B., Adhikari, B. Preparation, characterization and functional properties of flaxseed protein isolate. Food Chemistry, 2016, 197, 212-220. http://dx.doi.org/10.1016/j.foodchem.2015.09.106

Kazemi, M., Karim, R., Mirhosseini, H., Abdul Hamid, A. Optimization of pulsed ultrasound-assisted technique for extraction of phenolics from pomegranate peel of Malas variety: Punicalagin and Hydroxybenzoic Acids. Food Chemistry, 2016, 206, 156-166. http://dx.doi.org/10.1016/j.foodchem.2016.03.017

Loay, A.A., Taher, M.A. Influence of edible coatings chitosan/PVP blending with salicylic acid on biochemical fruit skin browning incidence and shelf life of guava fruits cv. 'Banati'. Scientia

Horticulturae, 2018, 235, 424-436. http://dx.doi.org/10.1016/j.scienta.2018.03.008

Mahfoudhi, N., Hamdi, S. Use of almond gum and gum arabic as novel edible coating to delay postharvest ripening and to maintain sweet cherry (Prunus avium) quality during storage. Journal of Food Processing and Preservation, 2014, 39, 1499-1508. http://dx.doi.org/10.1111/jfpp.12369

Mannozzi, C., Cecchini, J.P., Tylewicz, U., Siroli, L., Patrignani, F., Lanciotti, R., Rocculi, P., Dalla Rossa, M., Romani, S. Study on the efficacy of edible coatings on quality of blueberry fruits during shelf-life. LWT - Food Science and Technology, 2017, 85, 440-444. http://dx.doi.org/10.1016/j.lwt.2016.12.056
Marpalle, P., Sonawane, S.K., Arya, S.S. Effect of flaxseed flour addition on physicochemical and sensory properties of functional bread. LWT - Food Science and Technology, 2014a, 58, 614-619. http://dx.doi.org/10.1016/j.lwt.2014.04.003

Marpalle, P., Sonawane, S.K., LeBlanc, J.G., Arya, S.S. Nutritional characterization and oxidative stability of $\alpha$-linolenic acid in bread containing roasted ground flaxseed. LWT - Food Science and Technology, 2015b, 61, 510-515. http://dx.doi.org/10.1016/j.lwt.2014.11.018

Marquez, G.R., Pierro, P.D., Mariniello, L., Esposito, M., Giosafatto, C.V.L., Porta, R. Fresh-cut fruit and vegetable coatings by transglutaminase crosslinked whey protein/pectin edible films. LWT - Food Science and Technology, 2017, 75, 124-130. http://dx.doi.org/10.1016/j.lwt.2016.08.017

McCook-Russell, K.P., Nair, M.G., Facey, P.C., Bowen-Forbes, C.S. Nutritional and nutraceutical comparison of Jamaican Psidium cattleianum (strawberry guava) and Psidium guajava (common guava) fruits. Food Chemistry, 2012, 134, 10691073. http://dx.doi.org/10.1016/j.foodchem.2012.03.018

Moreira, B.R., Pereira-Júnior, M.A., Fernandes, K.F., Batista, K.A. An ecofriendly edible coating using cashew gum polysaccharide and polyvinyl alcohol. Food Bioscience, 2020, 37, 100722. http://dx.doi.org/10.1016/j.fbio.2020.100722

Mueller, K., Eisner, P., Yoshie-Stark, Y., Nakada, R., Kirchhoff, E. Functional properties and chemical composition of fractionated brown and yellow linseed meal (Linum usitatissimum L.). Journal of Food Engineering, 2010, 98, 453-460. http://dx.doi.org/10.1016/j.jfoodeng.2010.01.028

Murmu, S.B., Mishra, H.N. Optimization of the arabic gum based edible coating formulations with sodium caseinate and tulsi extract for guava. LWT - Food Science and Technology, 2017, 80, 271-279. http://dx.doi.org/10.1016/j.lwt.2017.02.018

Murmu, S.B., Mishra, H.N. The effect of edible coating based on arabic gum, sodium caseinate and essential oil of cinnamon and lemon grass on guava. Food Chemistry, 2018, 245, 820-828. http://dx.doi.org/10.1016/j.foodchem.2017.11.104

Naeem, A., Abbas, T., Ali, T.M., Hasnain, A. Effect of guar gum coatings containing essential oils on shelf life and nutritional quality of green-unripe mangoes during low temperature storage. International Journal of Biological Macromolecules, 2018, 113, 403-410. http://dx.doi.org/10.1016/j.ijbiomac.2018.01.224

Nair, M.S., Saxena, A., Kaur, C. Effect of chitosan and alginate based coatings enriched with pomegranate peel extract to extend the postharvest quality of guava (Psidium guajava L.). Food Chemistry, 2018, 
240, 245-252.

http://dx.doi.org/10.1016/i.foodchem.2017.07.122

Nawab, A., Alam, F., Hasnain, A. Mango kernel starch as a novel edible coating for enhancing shelf- life of tomato (Solanum lycopersicum) fruit. International Journal of Biological Macromolecules, 2017, 103, 581-586. http://dx.doi.org/10.1016/j.ijbiomac.2017.05.057

Oomah, B.D., Mazza, G. Flaxseed proteins- A review. Food Chemistry, 1993, 48, 109-114. http://dx.doi.org/10.1016/0308-8146(93)90043-f

Paniagua, A.C., East, A.R., Hindmarsh, J.P., Heyes, J.A. Moisture loss is the major cause of firmness change during postharvest storage of blueberry. Postharvest Biology and Technology, 2013, 79, 13-19. http://dx.doi.org/10.1016/j.postharvbio.2012.12.016

Pech, J.C., Bouzayen, M., Latche, A. Climacteric fruit ripening: Ethylene-dependent and independent regulation of ripening pathways in melon fruit. Plant science, 2008, 175, 114-120. http://dx.doi.org/10.1016/j.plantsci.2008.01.003

Riva, S.C., Opara, U.O., Fawole, O.A. Recent developments on postharvest application of edible coatings on stone fruit: A review. Scientia Horticulturae, 2020, 262, 109074. http://dx.doi.org/10.1016/j.scienta.2019.109074

Saberi, B., Golding, J.B., Marques, J.R., Pristijono, P., Chockchaisawasdee, S., Scarlett, C.J., Stathopoulos, C.E. Application of biocomposite edible coatings based on pea starch and guar gum on quality, storability and shelf life of 'Valencia' oranges. Postharvest Biology and Technology, 2018, 137, 920. http://dx.doi.org/10.1016/j.postharvbio.2017.11.003 Sarpong, F., Oteng- Darko, P., Golly, M.K., Amenorfe, L.P., Rashid, M.T., Zhou, C. Comparative study of enzymes inactivation and browning pigmentation of apple (Malus domestica) slices by selected gums during low temperature storage. Journal of Food Biochemistry, 2018, 42, e12681. http://dx.doi.org/10.1111/jfbc.12681

Sharma, S., Rao, T.V.R. Xanthan gum based edible coating enriched with cinnamic acid prevents browning and extends the shelf-life of fresh-cut pears. LWT - Food Science and Technology, 2015, 62, 791-800. http://dx.doi.org/10.1016/j.lwt.2014.11.050

Sharma, M., Saini, C.S. Postharvest shelf-life extension of fresh-cut guavas (Psidium guajava) using flaxseed protein- based composite coatings. Food Hydrocolloids for Health, 2021, 1, 100015. https://doi.org/10.1016/j.fhfh.2021.100015

Tahir, H.E., Xiaobo, Z., Mahunu, G.K., Arslan, M., Abdalhai, M., Zhihua, L. Recent developments in gum edible coating applications for fruits and vegetables preservation: A review. Carbohydrate
Polymers, 2019, 224, 115141. http://dx.doi.org/10.1016/j.carbpol.2019.115141

Treviño-Garza, M.Z., Correa-Cerón, R.C., OrtizLechuga, E.G., Solís-Arévalo, K.K., CastilloHernández, S.L., Gallardo-Rivera, C.T., Arévalo Niño, K. Effect of linseed (Linum usitatissimum) mucilage and chitosan edible coatings on quality and shelf-Life of fresh-cut cantaloupe (Cucumis melo). Coatings, 2019, 9, 368. http://dx.doi.org/10.3390/coatings9060368

Treviño-Garza, M.Z., García, S., Heredia, N., AlanísGuzmán, M.G., Arévalo-Niño, K. Layer-by-layer edible coatings based on mucilages, pullulan and chitosan and its effect on quality and preservation of fresh-cut pineapple (Ananas comosus). Postharvest Biology and Technology, 2017, 128, 63-75. http://dx.doi.org/10.1016/j.postharvbio.2017.01.007

Valero, D., Diaz-Mula, H.M., Zapata, P.J., Guillén, F., Martinez-Romero, D., Castillo, S., Serrano, M. Effects of alginate edible coating on preserving fruit quality in four plum cultivars during postharvest storage. Postharvest Biology and Technology, 2013, 77, 1-6. http://dx.doi.org/10.1016/j.postharvbio.2012.10.011

Ventura-Aguilar, R.I., Bautista-Baños, S., FloresGarcía, G., Zavaleta-Avejar, L. Impact of chitosan based edible coatings functionalized with natural compounds on Colletotrichum fragariae development and the quality of strawberries. Food Chemistry, 2018, 262, 142-149. http://dx.doi.org/10.1016/j.foodchem.2018.04.063

Yan, J., Luo, Z., Ban, Z., Lu, H., Li, D., Yang, D., Aghdam, M.S., Li, L. The effect of the layer-bylayer (LBL) edible coating on strawberry quality and metabolites during storage. Postharvest Biology and Technology, 2019, 147, 29-38.

http://dx.doi.org/10.1016/j.postharvbio.2018.09.002

Yousuf, B., Srivastava, A.K. Flaxseed gum in combination with lemongrass essential oil as an effective edible coating for ready-to-eat pomegranate arils. International Journal of Biological Macromolecules, 2017, 104, 1030-1038. http://dx.doi.org/10.1016/j.ijbiomac.2017.07.025

Zhang, L., Chen, F., Lai, S., Wang, H., Yang, H. Impact of soybean protein isolate-chitosan edible coating on the softening of apricot fruit during storage. LWT Food Science and Technology, 2018, 96, 604-611. http://dx.doi.org/10.1016/j.lwt.2018.06.011 